\title{
PEMETAAN DISTRIBUSI KEJADIAN DAN FAKTOR RISIKO STUNTING DI KABUPATEN BANGLI TAHUN 2019 DENGAN MENGGUNAKAN SISTEM INFORMASI GEOGRAFIS
}

\author{
Putu Aris Budiyasa Putra, Ni Luh Putu Suariyani* \\ Program Studi Sarjana Kesehatan Masyarakat Fakultas Kedokteran Universitas Udayana \\ ${ }^{*}$ Email:suar cph@yahoo.com
}

\begin{abstract}
ABSTRAK
Berdasarkan hasil Riskesdas 2018, Kabupaten Bangli menempati urutan pertama sebagai kebupaten dengan proporsi stunting tertinggi di Provinsi Bali, sebesar 43,2\%. Kejadian stunting dipengaruhi oleh multi faktor termasuk kewilyahan, geografis, bahkan demografis suatu wilayah. Penggambaran stunting dengan menggunakan SIG (Sistem Informasi Geografi) bermanfaat untuk mengetahui pola penyebaran kejadian stunting dan kaitan kejadian stunting dengan faktor risiko stunting pada suatu wilayah. Penelitian ini menggunakan rancangan crossectional deskriptif dengan menampilkan data sekunder sebaran jumlah kasus stunting dan faktor risikonya dengan pengolahan data dilakukan menggunakan aplikasi pengolahan peta dalam proses SIG. Hasil penelitian menggambarkan kasus stunting tersebar di seluruh kecamatan dengan kasus tertinggi ada di Kecamatan Susut dan yang terendah di Kecamatan Bangli. Pada beberapa daerah dengan kasus stunting yang tinggi berada jauh dari layanan puskesmas. Wilayah Kabupaten Bangli didominasi daerah rural dengan sebaran kasus yang banyak terdapat di wilayah rural. Kasus stunting banyak dijumpai di wilayah dataran sedang dan pegunungan. Beberapa wilayah yang memiliki cakupan Jamban Sehat Permanen (JSP) rendah memiliki kasus stunting yang tinggi. Pola kasus stunting di Kabupaten Bangli tahun 2019 beserta faktor risikonya dapat digambarkan melalui peta sebaran kasus stunting dan layering tiap faktor risikonya. Disarankan agar dapat mempertimbangkan peta sebaran stunting dalam pengambilan kebijakan penanganan stunting di Kabupaten Bangli.
\end{abstract}

Kata kunci: Stunting, Pemetaan, SIG

\section{ABSTRACT}

Based on 2018 Riskesdas, Bangli Regency take first place as a district with the highest proportion of stunting in the Province of Bali, around $43.2 \%$. The occurrence of stunting is influenced by multiple factors including, geographical, and even demographic of the areas. descript stunting using GIS (Geographic Information System) is useful to find out the pattern of the spread of stunting and the relationship of stunting events to the risk factors of stunting in an area. This study was used a descriptive cross-sectional design. It descript the distribution of stunting number and risk factors used a map processing application in the GIS process. The results of the study illustrate stunting cases spread across all over the districts with the highest cases in Susut District and the lowest in Bangli District. In some areas with high cases of stunting, they are far from puskesmas services. The Bangli Regency is dominated by rural areas with a large distribution of cases in rural areas. Stunting cases are often found in the plains and mountains. Some areas that have low coverage of Healthy Latrine (JSP) have high number of stunting. The pattern of the occurrence of stunting cases in Bangli Regency in 2019 along with the risk factors can be illustrated through a map of the distribution of stunting cases and layering of each risk factor. It is recommended to be able to consider stunting distribution maps in making stunting policy in Bangli Regency.

Keywords: Sunting, Maping, GIS

\section{PENDAHULUAN}

Stunting atau balita kerdil merupakan keadaan tubuh balita yang pendek dan sangat pendek hingga melampaui defisit -2 SD di bawah median panjang atau tinggi badan anak pada usianya (Budiastutik \& Rahfiludin, 2019). Pada tahun 2017 terdapat 22,2\% atau sekitar 150,8 juta balita di dunia mengalami stunting. Lebih dari setengah balita stunting di dunia berasal dari Asia (55\%) sedangkan lebih dari sepertiganya (39\%) tinggal di Afrika. Dari 83,6 juta balita stunting di Asia, proporsi terbanyak berasal dari Asia Selatan $(58,7 \%)$ dan proporsi paling sedikit di Asia Tengah (0,9\%). Data prevalensi balita stunting yang dikumpulkan World 
Health Organization (WHO), Indonesia termasuk ke dalam negara ketiga dengan prevalensi tertinggi di regional Asia Tenggara/South-East Asia Regional (SEAR). Rata-rata prevalensi balita stunting di Indonesia tahun 2005-2017 adalah 36,4\% (Kemenkes RI, 2018). Prevalensi balita dengan tinggi badan pendek di Provinsi Bali sendiri pada tahun 2017 adalah 19\% (Dinkes Bali, 2018). Angka stunting di Bali berdasarkan riskesdas tahun 2018 yaitu sebesar 21,9\%. Kabupaten Bangli pada tahun 2018 menjadi salah satu kabupaten dengan prevalensi balita pendek tertinggi yang ada di Provinsi Bali yakni sebesar 28,4\%. Dari 12 wilayah kerja puskesmas yang dimiliki Kabupaten Bangli 10 diantaranya memiliki persentase balita pendek yang lebih tinggi dari 20\% pada tahun 2018 (Dinkes Bangli, 2019). Berdasarkan hasil Riskesdas 2018 Kabupaten Bangli menempati urutan pertama sebagai kebupaten dengan proporsi stunting tertinggi di Provinsi Bali, yakni sebesar 43,2\%, tentu proporsi tersebut jauh melebihi ambang masalah kesehatan masyarakat yakni sebesar 20\% (Riskesdas, 2018).

Kondisi stunting pada balita dapat menimbulkan berbagai dampak negatif baik dalam jangka waktu pendek maupun jangka waktu panjang. Kemenkes RI (2018) menginformasikan pada balita yang mengalami stunting umumnya lebih rentan mengalami kejadian kesakitan bahkan kematian, sehingga banyak biaya dihabiskan untuk pengobatan. Stunting dapat menyebabkan terganggunya perkembangan kognitif, motorik, dan verbal dari anak itu sendiri. Dalam jangka waktu panjang stunting dapat menyebabkan postur tubuh yang tidak optimal saat dewasa (lebih pendek dibandingkan pada umumnya); meningkatnya risiko obesitas dan penyakit lainnya; menurunnya kesehatan reproduksi; kapasitas belajar dan performa yang kurang optimal saat masa sekolah; serta produktivitas dan kapasitas kerja yang tidak optimal (Kemenkes RI, 2018).

Stunting disebabkan oleh faktor multi dimensi dan tidak hanya disebabkan oleh faktor gizi buruk yang dialami oleh ibu hamil maupun anak balita. Sekretariat Wakil Presiden RI telah mengklasifikasikan beberapa faktor yang mempengaruhi kejadian balita pendek atau stunting diantaranya praktek pengasuhan, layanan Ante Natal Care (ANC) dan Post Natal Care (PNC), akses rumah tangga / keluarga ke makanan bergizi, dan kurangnya akses air bersih dan sanitasi (TNP2K, 2017). Faktor faktor lain yang mempengaruhi kejadian stunting pada masyarakat juga dapat dipengaruhi oleh faktor kewilyahan, geografis, bahkan demografis suatu wilayah. Penelitian di Ethiopia menunjukan bahwa kejadian stunting di daerah tersebut tidak tersebar secara acak, melainkan kasus stunting cenderung banyak terjadi di wilayah Ethiopia bagian utara, hal tersebut menunjukan kejadian stunting lebih banyak terjadi daerah dataran tinggi dan sedang dari pada di dataran rendah. (Haile et al, 2016).

Kejadian stunting di Kabupaten Bangli tersebar hampir di seluruh wilayah Kabupaten Bangli. Berdasarkan hasil wawancara yang dilakukan dengan Kasi Gizi Kesmas dan Kesehatan Keluarga Dinas Kesehatan Kabupaten Bangli, Dinas Kesehatan Kabupaten Bangli 
sesungguhnya telah melakukan berbagai upaya dalam penanganan kasus stunting seperti intervensi spesifik maupun sensitif. Namun meski demikian kasus stunting masih mengalami peningkatan, sehingga perlu mempertimbangkan faktor risko lain dari kejadian stunting seperti dari segi geografi. Dinas Kesehatan Kabupaten Bangli telah memiliki data - data terkait kejadian stunting maupun faktor risiko yang mempengaruhi kejadian stunting pada bayi di Kabupaten Bangli, namun data - data tersebut masih disimpan tersendiri pada sub bagain gizi dan kesehatan lingkungan. Informasi terkait stunting pada umumnya masih diolah secara manual dengan disajikan dalam bentuk tabel serta grafik, sehingga masih sulit dilihat dari sisi kewilayahan, padahal kejadian stunting juga dapat dipengaruhi oleh kondisi kewilayahan masyarakat setempat. Salah satu alternatif visualisasi kejadian yang dapat digunakan Dinas Kesehatan Kabupaten Bangli adalah peta.

Peta adalah suatu representasi atau gambaran unsur-unsur atau kenampakan abstrak, yang dipilih dari permukaan bumi, atau yang ada kaitannya dengan permukaan bumi, dan umumnya digambarkan pada suatu bidang datar dan diperkecil/diskalakan. Peta yang berisikan kondisi epidemilogis suatu kejadian dapat digambarkan menggunakan Sistem Informasi Geografis. Sistem Informasi Geografis (SIG) merupakan salah satu jenis visualisasi epidememiologi yang dapat dimanfaatkan untuk menunjukan gambaran dalam bentuk peta dari distribusi suatu kondisi berdasarkan analisis kewilayahan. Melalui analisis kewilayahan penentu kebijakan dapat lebih mudah mengetahui permasalahan, untuk selanjutnya dapat mengambil kebijakan yang tepat (Adimas \& Bilal, 2019). SIG dapat membantu pihak yang membutuhkan untuk melihat pola sebaran kejadian stunting serta kaitannya dengan faktor risiko stunting melalui perspektif kewilayahan.

Kejadian stunting serta faktor risiko stunting di Kabupaten Bangli perlu ditampilkan dari perspektif kewilayahan, mengingat Kabupaten Bangli merupakan kabupaten yang memiliki wilayah geografis dataran yang bevariasi, serta kondisi wilayah yang juga bervariasi (Dinkes Bangli, 2019). Penggambaran stunting dengan menggunakan SIG dapat bermanfaat untuk mengetahui pola penyebaran kejadian stunting, kaitan kejadian stunting dengan faktor risiko stunting pada suatu wilayah, daerah yang dapat dijadikan lokus penanganan stunting dan lokasi penting untuk menyediakan fasilitas kesehatan masyarakat seperti puskesmas yang memadai dan dapat dijangkau oleh masyarakat sebagai tempat untuk memperoleh pengobatan ataupun tindakan pencegahan terkait kondisi stunting (Megawaty \& Simanjuntak, 2017).

\section{METODE PENELITIAN}

Penelitian ini menggunakan rancangan crossectional deskriptif karena ingin menggambarkan potensi stunting di Kabupaten Bangli. Penelitian ini dilakukan selama enam bulan di Kabupaten Bangli dari Bulan Februari sampai Juni 2020. Unit analisis dalam penelitian ini adalah unit administrasi desa dengan sampel merupakan seluruh jumlah kasus stunting per desa. Data yang dikumpulkan dalam 
merupakan data sekunder. Pengolahan data dilakukan dengan menggunakan aplikasi pengolahan peta dalam proses SIG.

\section{HASIL DAN DISKUSI}

\section{Distribusi Kasus Stunting di Kabupaten Bangli}

Berdasarkan data sekunder kasus stunting (bayi pendek dan sangat pendek) tahun 2019 yang didapatkan dari Dinas Kesehatan Kabupaten Bangli dan TPG masing - masing Puskesmas diketahui bahwa sebaran stunting di masing - masing desa di Kabupaten Bangli memiliki besaran yang bervariasi. Namun sayangnya untuk lima desa dari enam desa yang berada di wilayah Puskesmas Kintamani IV tidak memiliki data yang valid terkait jumlah kasus stunting tahun 2019. Lima desa tersebut anata lain : Abang Batu Dinding, Abang Songan, Kedisan, Suter, dan Terunyan. Peneliti melakukan konfirmasi secara daring dengan TPG dari Puskesmas IV Kintamani, menurut beliau data stunting tahun 2019 masih belum dapat diinput sepenuhnya akibat terkendala sinyal dan kurangnya tenaga penginput data. Daerah tersebut secara geografis merupakan daerah memiliki keterbatasan akses jalan maupun akses infrastruktur penunjang komunikasi. Hasil serupa ditemukan dalam penelitian yang dilakukan oleh Kazwaini dan Nugraheni (2014) dimana beberapa kendala juga dirasakan oleh petugas dalam melakukan pendataan surveilans ibu hamil, bayi, dan balita di Puskesmas Unit I, Puskesmas Moyo, dan Dinas Kesehatan Kabupaten Sumbawa, diantaranya : data hanya bersumber pada masyarakat yang datang ke posyandu, migrasi penduduk yang tidak terdeteksi dalam rentang waktu pelaporan, terbatasnya sarana teknis pelaporan, petugas mempunya fungsi ganda atau merangkap tugas pokok dan fungsi lain, jarang sekali dilakukan kroscek antar pemegang program yang terkait sebelum membuat rekap bulanan (Kazwaini \& Nugraheni, 2014).

Berikut ini adalah peta choropleth distribusi kasus stunting di Kabupaten Bangli tahun 2019. 


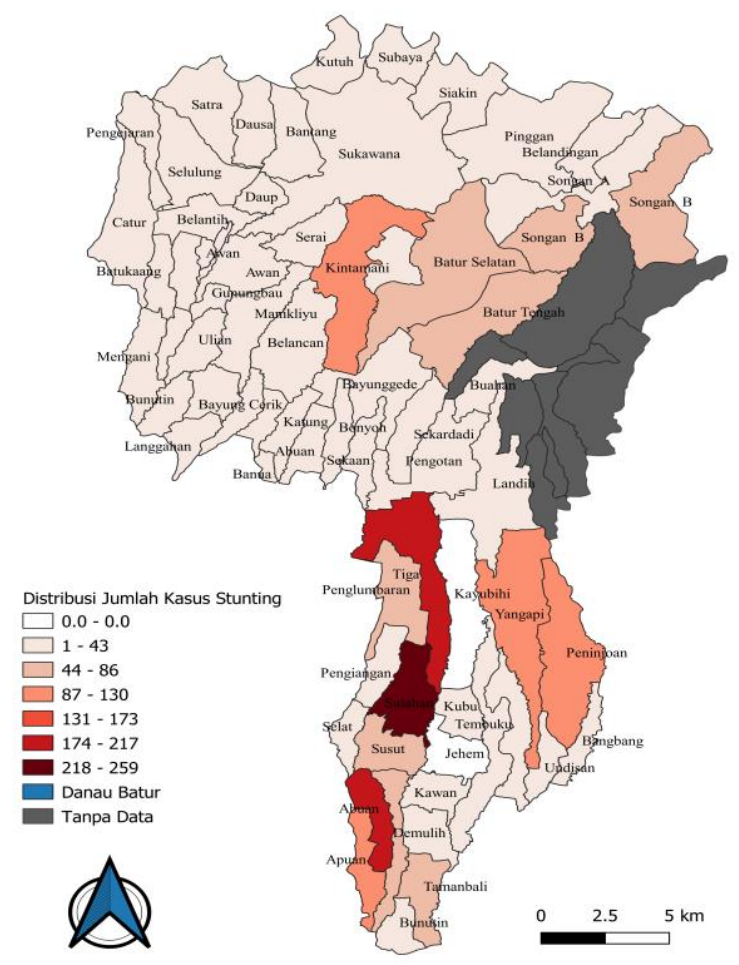

\section{Gambar 1. Distribusi Kasus Stunting Per Desa di Kabupaten Bangli Tahun 2019}

Bedasarkan peta tersebut dapat dilihat bahwa desa - desa yang tidak memiliki data kasus stunting berada di sebelah timur Danau Batur dan Gunung Batur. Persebaran kasus stunting di wilayah barat Kecamatan Susut (Desa Sulahan, Desa Abuan, Desa Tiga, dan Desa Apuan) cenderung paling tinggi jika dibandingkan daerah lainnya. Dapat dilihat pula wilayah bagian tenggara Kecamatan Timur (Desa Yangapi dan Desa Peninjoan) dan wilayah Kecamatan Kintamani di sekitaran Danau Batur dan Gunung Batur (Desa Songan B, Desa Batur Selatan, Desa Batur Tengan) serta Desa Kintamani juga memiliki kasus stunting yang lebih tinggi dari wilayah lainnya. Distribusi kasus stunting di Kecamatan Kintamani cenderung merata hampir di seluruh desa - desa yang ada di Kecamatan Kintamani (1 - 43 kasus), kecuali desa - desa yang ada di sekitaran Danau Batur dan Gunung Batur yang terlihat lebih tinggi. Sedangkan terdapat dua desa di bagian tengah Bangli yang tidak memiliki kasus balita stunting, yakni Kelurahan Cempaga dan Desa Kayubihi. Desa - desa di Kecamatan Susut memiliki kasus stunting yang bervariasi namun cenderung tinggi.

Kasus stunting tertinggi terdapat di Kecamatan Susut sebanyak 965 kasus, kemudian diikuti Kecamatan Kintamani sebanyak 743 kasus, kemudian diikuti dengan Kecamatan Tembuku sebanyak 194 kasus, dan paling sedikit adalah Kecamatan Bangli sebanyak 142 kasus. Perlu diperhatikan bahwa lima wilayah yang tidak memiliki data kasus stunting (Abang Batu Dinding, Abang Songan, Kedisan, Suter, dan Terunyan) berada di wilayah Kecamatan Kintamani, sehingga total kasus di wilayah Kecamatan Kintamani bisa saja lebih besar. Terlihat pula terdapat ketimpangan jumlah kasus 
stunting yang cukup besar antara dua kecamatan dengan kasus tertinggi (Susut dan Kintamani) dengan dua kecamatan lainnya (Bangli dan Tembuku). Kejadian stunting di Kabupaten Bangli cenderung mengelompok di beberapa daerah, seperti di sekitar Desa Sulahan dan sekitarnya, Desa Yangapi dan Peninjoan, serta di sepuataran Danau Batur dan Gunung Batur.

$$
\text { Kejadian stunting yang }
$$

mengelompok di suatu wilayah tersebut sesuai dengan beberapa penelitian stunting yang yang memanfaatkan GIS di beberapa negara. Penelitian yang dilakukan oleh Almazi dkk (2019) menemukan center mean dan standar deviasi stunting paling banyak ditemukan di negara - negara Afrika dan Asia. Pada jurnal tersebut juga diungkapkan beberapa penelitian serupa Hasan et al. (2018) di Bangladesh, dan Gebreyesus et al. (2016) di Ethiopia menunjukan hasil seorang anak yang lahir di wilayah cluster stunting cenderung empat kali lebih berisiko mengalami stunting jika dibandingkan anak yang lahir di luar cluster stunting. Kejadian stunting di daerah cluster stunting tidak lagi hanya dipengaruhi oleh faktor risiko seperti kesakitan pada balita, diversivikasi pangan, maupun ketahangan pangan. Dalam penelitian tersebut dijelaskan daerah cluster stunting memiliki beberapa faktor risiko yang mempengaruhi kejadian stunting seperti gaya hidup masyarakat, kepercayaan, serta akses menuju layanan kesehatan. Kemiskinan pada suatu daerah juga mempengaruhi pola pemberian makanan yang kurang baik kepada balita yang mempengaruhi kondisi stunting (Almasi et al., 2019). Kondisi ini juga didapatkan pada penelitian Danila dkk (2019) yang menemukan kejadian stunting cenderung mengelompok di wilayah tertentu di Kabupaten Manggarai, NTT dan didapatkan terdapat hubungan yang signifikan antara kejadian stunting dengan kondisi geografis setempat.

Variasi sebaran kasus stunting di Kabupaten Bangli dapat dipengaruhi oleh berbagai faktor risiko. Pada penelitian yang dilakukan oleh Haile dkk (2016) menunjukan hasil bahwa daerah urban memiliki prevalensi kasus stunting yang lebih rendah dibandingkan daerah rural. Hal tersebut sesuai dengan gambar 1 dimana kejadian stunting di Kecamatan Bangli sebagai daerah ibu kota kabupaten memiliki kasus stunting paling rendah dibandingkan daerah lainnya. Dalam penelitian Haile juga ditemukan kasus stunting lebih banyak ditemukan di wilayah bagian utara, dimana daerah tersebut memiliki karakteristik dataran tinggi dan sedang (Haile et al., 2016). Hal ini sesuai dengan karakteristik Kabupaten Bangli yang didominasi oleh dataran tinggi dan sedang.

Dalam penelitian ini tentunya masih terdapat kelemahan - kelemahan yang dialami, khusunya dalam ketersediaan data penelitian. Data kasus stunting yang tersedia bagi peneliti hanya berupa angka absolute jumlah kasus stunting perdesa, sehingga tidak dapat menggabarkan persentase kejadian dalam suatu daerah. Hal tersebut menyebabkan peta yang dihasilkan tidak mampu menggambarkan cut of point dari kasus stunting yang disyaratkan yakni sebesar $20 \%$ dari populasi balita pada suatu daerah. Angka absolute tersebut juga 
kurang dapat menggambarkan perbandingan kejadian antar daerah mengingat adanya perbedaan populasi balita antar daerah.

\section{Distribusi Kasus Stunting Dengan} Jangkauan Layanan Puskesmas di Kabupaten Bangli

Puskesmas di Kabupaten Bangli terdapat 12 buah yang tersebar di empat kecamatan di Kabupaten Bangli. Luas wilayah yang masih efektif untuk sebuah sarana pelayanan kesehatan seperti Puskesmas adalah suatu area dengan jarijari $5 \mathrm{~km}$, sedangkan luas wilayah kerja yang dipandang optimal adalah area dengan jari-jari $3 \mathrm{~km}$, jadi jarak antar Puskesmas adalah 3 sampai $5 \mathrm{~km}$ (Departemen Kesehatan, 1991).

Berikut merupakan peta jarak jangkauan layanan 12 puskesmas di Kabupaten Bangli.

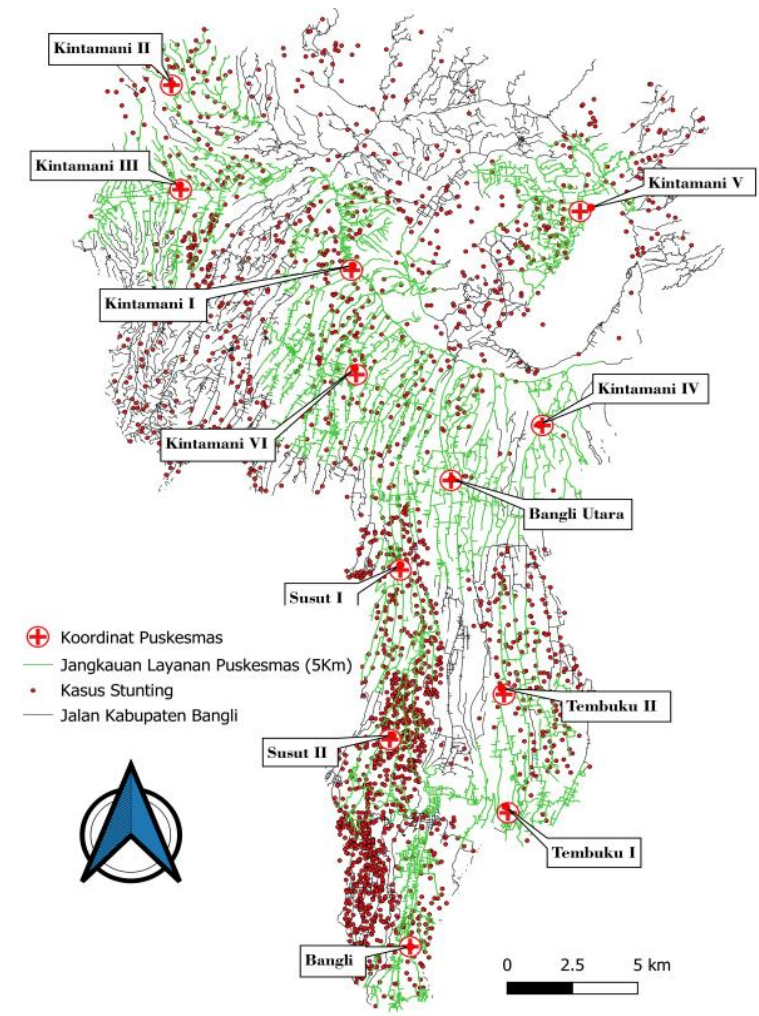

Gambar 2. Distribusi Kasus Stunting Dengan Jangkauan Wilayah Puskesmas di Kabupaten Bangli Tahun 2019

Peta pada gambar tersebut menunjukan penampakan jalan - jalan yang terdapat di Kabupaten Bangli, disertai dengan dot jumlah kasus stunting di setiap desa / kelurahan yang ada di Kabupaten Bangli. Peta tersebut juga menunjukan titik koordinat dari 12 Puskesmas yang ada di Kabupaten Bangli. Jalan berwarna hijau menunjukan bahwa masyarakat disekitar jalan tersebut memiliki akses sekitar $5 \mathrm{Km}$ menuju puskesmas terdekat. Sedangkan jalan yang masih berwarna hitam menujukkan masyarakat di daerah tersebut berada di luar $5 \mathrm{Km}$ akses jangkauan menuju puskesmas terdekat.

Pada bagian barat Kecamatan Susut terlihat bahwa beberapa desa yang berada 
di wilayah tersebut memiliki akses jalan raya yang melebihi $5 \mathrm{~km}$ menuju puskesmas terdekat. Desa tersebut diantaranya Apuan, Abuan, Demulih dan sekitarnya. Pada daerah - daerah tersebut kasus stunting paling banyak terjadi jika dibandingkan daerah lainnya di Kabupaten Bangli. Pada bagian tengan Kecamatan Bangli dan timur Kecamatan Tembuku juga terdapat beberapa desa / kelurahan yang memiliki akses jalan raya lebih dari $5 \mathrm{Km}$. Pada bagian tengah diantaranya Desa Kayubihi dan Kubu, serta disebelah timur di Desa Peninjoan Tembuku dan sekitarnya. Pada daerah timur Kecamatan Tembuku kasus stunting cukup banyak terjadi. Sedangkan pada daerah tengah Kecamatan Bangli kasus stunting justru terlihat sangat sedikit. Di wilayah bagian tenggara Kecamatan Kintamani terdapat beberapa desa dengan akses jalan raya yang masih melebihi dari jaraka $5 \mathrm{Km}$ menuju puskesmas terdekat. Desa tersebut diantaranya Bunutin, Ulian, Manikliyu, Mengani, Awan, Belangan, dan beberapa wilayah lain di sekitarnya. Pada daerah tersebut kejadian stunting terjadi cukup merata dalam jumlah yang cukup banyak di seluruh bagian. Wilayah lain yang memiliki jarak lebih dari $5 \mathrm{Km}$ adalah di bagian utara hingga timur laut Kecamatan Kintamani, daerah tersebut meliput banyak desa di seputaran Danau Batur dan Gunung Batur. Pada daerah daerah tersebut kasus stunting terjadi mengelompok di beberapa desa, namun sayangnya di daerah sekitaran Danau Batur (daerah timur Danau Batur) kasus stunting sebagain besar masih belum tercatat secara pasti jumlahnya.
Sebuah penelitian yang dilakukan di Indonesia oleh Ma'Rifat (2010) mengelompokan jarak, waktu tempuh dan ketersediaan transportasi menuju akses layanan kesehatan dalam variabel akses ke pelayanan kesehatan. Hasil dari penelitian tersebut menujukan semakin jauh jarak tempuh seseorang menuju pusat layanan kesehatan akan menurunkan frekuensi kunjungan ke pelayanan kesehatan, sehingga secara tidak langsung dapat mempengaruhi status gizi balita termasuk dalam kejadian stunting (Ma'Rifat, 2010). Penelitian serupa juga pernah dilakukan oleh Sartika (2010) dimana hasil analisis bivariat menunjukkan proporsi kejadian malnutrisi (BB/U, TB/U, dan BB/TB) pada balita lebih tinggi terjadi pada balita dengan jarak rumah $>300$ meter, waktu tempuh $>7$ menit dan tidak mempunyai alat transportasi ke pelayanan kesehatan (nilai $\mathrm{p}<0,05)($ Sartika, 2010). Hasil dari dua penelitian tersebut dapat terlihat pada gambar 2 dimana beberapa daerah di Kabupaten Bangli yang berada jauh dari puskesmas memiliki kejadian stunting yang tinggi. Daerah - daerah tersebut mencangkup sebelah barat Kecamatan Susut, Sebelah Timur Kecamatan Tembuku, sebelah tenggara Kecamatan Kintamani, serta beberapa wilayah di seputaran Danau Batur dan Gunung Batur. Beberapa daerah dengan kasus stunting yang rendah juga berada dalam jarak $5 \mathrm{Km}$ dari jangkauan Puskesmas, seperti misalnya di wilayah sekitar UPT Bangli Utara dan Kintamani III. Pada beberapa daerah meskipun telah memiliki akses yang dekat menuju puskesmas namun masih memiliki kasus stunting yang cukup tinggi. 
Penelitian lain yang memanfaatkan GIS mengenai hubungan antara kejadian stunting dengan jarak menuju pusat layanan kesehatan dilakukan oleh Madan (2014). Beberapa hasil penelitian tersebut menunjukan pada beberapa daerah seperti Mopti, Segou dan Kayes yang memiliki risiko stunting yang tinggi memiliki jarak yang jauh dengan pusat pelayanan kesehatan, sedangkan untuk beberapa daerah seperti Sikasso dan Koulikoro memiliki jarak ke pusat layanan kesehatan yang lebih dekat namun memiliki potensi stunting yang masih cukup tinggi. Di beberapa daerah yang memiliki risiko stunting rendah memiliki jarak yang dekat dengan pusat pelayanan kesehatan setempat (Madan, 2014). Hal tersebut dapat menggambarkan hasil sebaran deskriptif kasus stunting dan jangkauan layanan kesehatan pada gambar 2 yang mana pada beberapa daerah yang memiliki akses jalan raya lebih dari $5 \mathrm{Km}$ menuju puskesmas seperti daerah Apuan, Abuan, dan beberapa daerah di sekitarnya memiliki kasus stunting yang sangat tinggi. Pada beberapa daerah lain yang sesungguhnya telah memiliki akses yang dekat menuju puskesmas ternyata juga masih memiliki kasus stunting dengan jumlah yang bervariasi. Sehingga perlu dilakukan pendekatan analitik untuk melihat lebih lanjut hubungan jarak layanan puskesmas di Kabupaten Bangli dengan sebaran kasus stunting.

Akses layanan kesehatan tidak selalu bergantung terhadap layanan puskesmas, namun juga akses menuju layanan kesehatan lainnya. Puskesmas sebagai unit pelaksana dari dinas kesehatan juga dibatu beberapa Pustu
(Puskesmas Pembantu), Polindes (Pondok Bersalin Desa), serta Poskesdes (Pos Kesehatan Desa) di beberapa wilayahnya. Menurut data dari Dinas Kesehatan Kabupaten Bangli, jumlah Pustu sebanyak 59 buah, Polindes 6 buah, Poskesdes 26 buah. Pada beberapa daerah yang meskipun berada jauh dari Puskesmas namun memiliki kasus stunting yang rendah, kemungkinan berkaitan dengan pusat layanan kesehatan lainnya yang berada di daerah tersebut. Hal tersebut dapat dilihat pada Desa Kayubihi dan Kubu yang berada jauh dari Puskesmas terdekat namun memiliki kasus stunting yang sangat rendah. Menurut data BPS Bangli (2019) di Desa Kubu terdapat 1 Pustu, 5 Posyandu, dan 2 dokter praktek. Desa Kayubihi memiliki 3 Pustu dan 10 Posyandu. Jika dibandingkan dengan Desa Abuan dan Apuan yang jauh dari Puskesmas dan memiliki kasus stunting yang tinggi, ternyata memiliki fasilitas kesehatan yang lebih sedikit. Menurut data BPS Bangli (2019) Desa Apuan memiliki 1 Pustu, dan 4 Posyandu. Desa Abuan memiliki 1 Pustu, 4 Posyandu, dan 2 Dokter Praktek. Bahkan jika dibandingkan dengan desa - desa yang berada di wilayah tenggara Kintamani yang memiliki karakteristik serupa dengan Abuan dan Apuan seperti Mengani, Binyan, Ulian, Langgahan, Lembean, dan beberapa wilayah disekitarnya kebanyakan hanya memiliki 1 sampai 2 posyandu, dan beberapa memiliki 1 Pustu di desanya (BPS Bangli, 2019).

Dalam hasil penelitian tersebut tentu juga masih memiliki beberapa kelemahan. Titik atau dot dari masing masing kasus stunting tidak menunjukan 
lokasi sebenarnya dari anak yang mengalami stunting, namun hanya titik sembarang untuk menggambarkan jumlah kasus di setiap desa. Selain hal tersebut, kondisi beberapa daerah di bagian timur Kecamatan Kintamani yang minim akses dari wilayah puskesmas setempat ternyata cenderung lebih dekat diakses melalui wilayah Kabupaten Karangasem, namun akibat keterbatasan network analysis pada software sehingga kondisi tersebut tidak dapat ditampilkan pada peta.

\section{Distribusi Kasus Stunting Dengan Status} Rural / Urban Desa di Kabupaten Bangli

Berikut merupakan peta gambaran status rural urban di Kabupaten Bangli dengan sebaran kasus stunting.

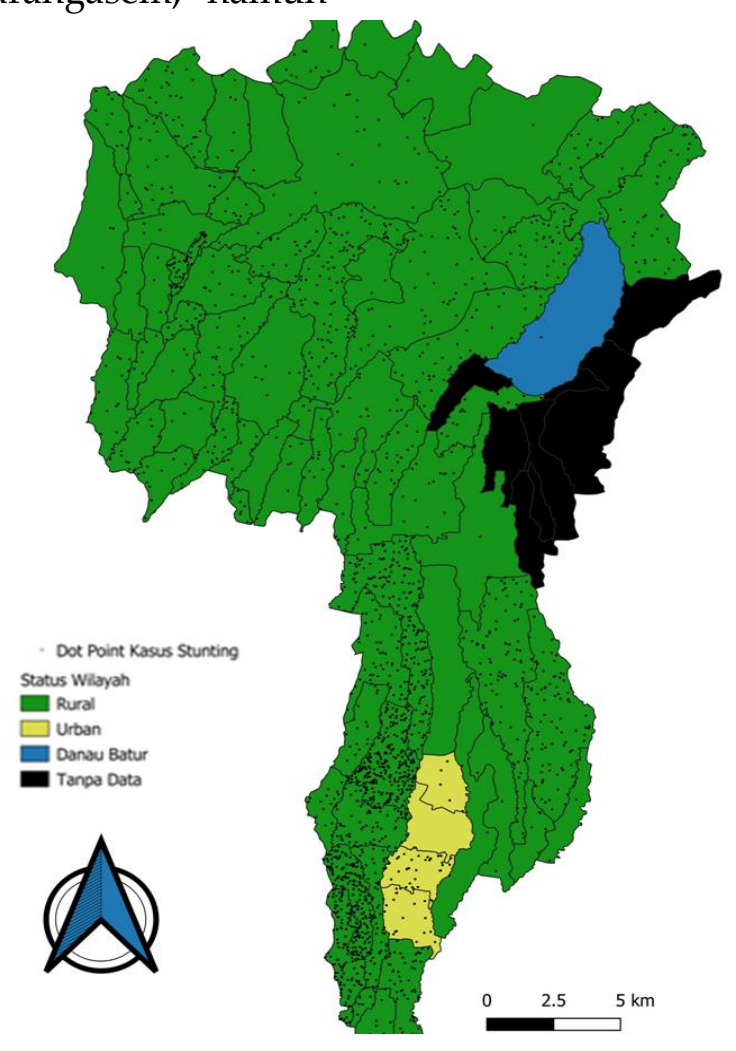

Gambar 3. Distribusi Kasus Stunting Dengan Status Rural Urban Desa di Kabupaten Bangli Tahun 2019

Berdasarkan peta tersebut dapat dilihat dari 73 kelurahan / desa yang terdapat di Kabupaten Bangli yang berstatus sebagai daerah urban hanya 4 buah desa / kelurahan, sedangkan 69 wilayah lainnya berstatus sebagai daerah rural. Empat desa / kelurahan tersebut seluruhnya berada di Kecamatan Bangli, yakni Bebalang, Cempaga, Kawan, dan Kubu. Dari keempat wilayah tersebut, Kelurahan Cempaga menjadi salah satu dari dua wilayah di Kabupaten Bangli yang tidak memiliki kasus stunting pada tahun 2019. Pada daerah - daerah dengan kasus stunting yang tinggi seperti Desa Sulahan, Abuan, Apuan, Tiga, Kintamni dan daerah lainnya yang memiliki kasus stunting tertinggi berada di daerah rural. Dapat diperhatikan perbandingan dot jumlah kasus stunting di wilayah urban yang berwarna kuning jauh lebih rendah jika dibandingkan dengan dot jumlah kasus pada wilayah rural yang berada di 
sebelah barat (sebelah kiri) wilayah urban tersebut.

Berbagai penelitian mengenai kejadian stunting yang telah dilakukan di seluruh dunia seperti Haile dkk (2016) di Ethiopia, Cruz dkk (2017) di Mozambique, Laksono \& Kusrini (2019) di negara - negara berkembang menemukan hubungan yang bermakna antara status rural urban daerah dengan kejadian stunting di daerah tersebut. Hal tersebut berkaitan dengan berbagai hal seperti tingkat pendidikan orang tua, jenis pekerjaan, status ekonomi, dan beberapa hal lainnya. Pada penelitian yang dilakukan oleh Cruz dkk menemukan hasil anak yang tinggal di daerah urban memiliki risiko yang jauh lebih rendah mengalami stunting jika dibandingkan anak yang tinggal di daerah rural [AOR = 138.0, 95\% CI $=(32.38-587.80), \mathrm{p}<0.001]$ (Francisco, Ferrer, \& Serra-majem, 2017). Pada gambar 3 menunjukan peta sebaran kasus stunting di daerah rural atau urban yang berada di Kabupaten Bangli, namun sayangnya cukup sulit untuk melihat perbandingan deskriptif antara sebaran kasus stunting di daerah urban dan rural akibat sangat sedikitnya desa / kelurahan yang termasuk dalam kawasan urban (4 desa) jika dibandingkan wilayah yang termasuk kawasan rural (69 desa). Jika diperhatikan jumlah kasus stunting di keempat desa / kelurahan yang berstaus urban tersebut memang lebih sedikit jika dibandingkan daerah lainnya. Kasus paling banyak pada daerah urban terdapat di wilayah Kawan yakni 33 kasus. Kelurahan Cempaga bahkan sama sekali tidak memiliki kasus stunting pada tahun 2019, Kelurahan Cempaga menjadi salah satu dari dua wilayah yang tidak memiliki kasus stunting pada tahun 2019.

Sebuah penelitian yang dilakukan oleh Lusita dkk (2017) membandingkan karakteristik kasus stunting di wilayah perkotaan (urban) dan pedesaan (rural). Pada penelitian tersebut beberapa variabel yang bermakna $(\mathrm{p}<0,005)$ adalah lama pendidikan ibu, tingkat pengetahuan gizi ibu, dan durasi sakit ISPA. Selain variabel tersebut penelitian ini juga melihat Nilai Z- score yang menunjukkan pertumbuhan balita. Pada penelitian ini nilai Z-score balita di pedesaan lebih rendah dibandingkan dengan nilai Z-score balita stunting yang berada di perkotaan. Hal tersebut dikarenakan asupan makanan yang baik ditemukan pada kelompok balita yang tinggal di perkotaan. Hal tersebut dapat dilihat pada tingkat konsumsi protein, dimana tingkat konsumsi protein kategori baik paling banyak ditemukan pada balita stunting di perkotaan dibandingkan dengan pedesaan. Status ekonomi yang tinggi juga paling banyak ditemukan pada responden di wilayah perkotaan, sehingga akan mempengaruhi konsumsi makanan balita, yang nantinya akan berpengaruh terhadap pertumbuhan dan perkembangannya (Aprilliyani Pepi Lusita et al., 2017).

\section{Dinstribusi Kasus Stunting Dengan Zona Ekosistem Daerah di Kabupaten Bangli}

Berikut merupakan peta gambaran sebaran kasus stunting dengan zona ekosistem wilayah masing - masing desa / kelurahan di Kabupaten Bangli. 


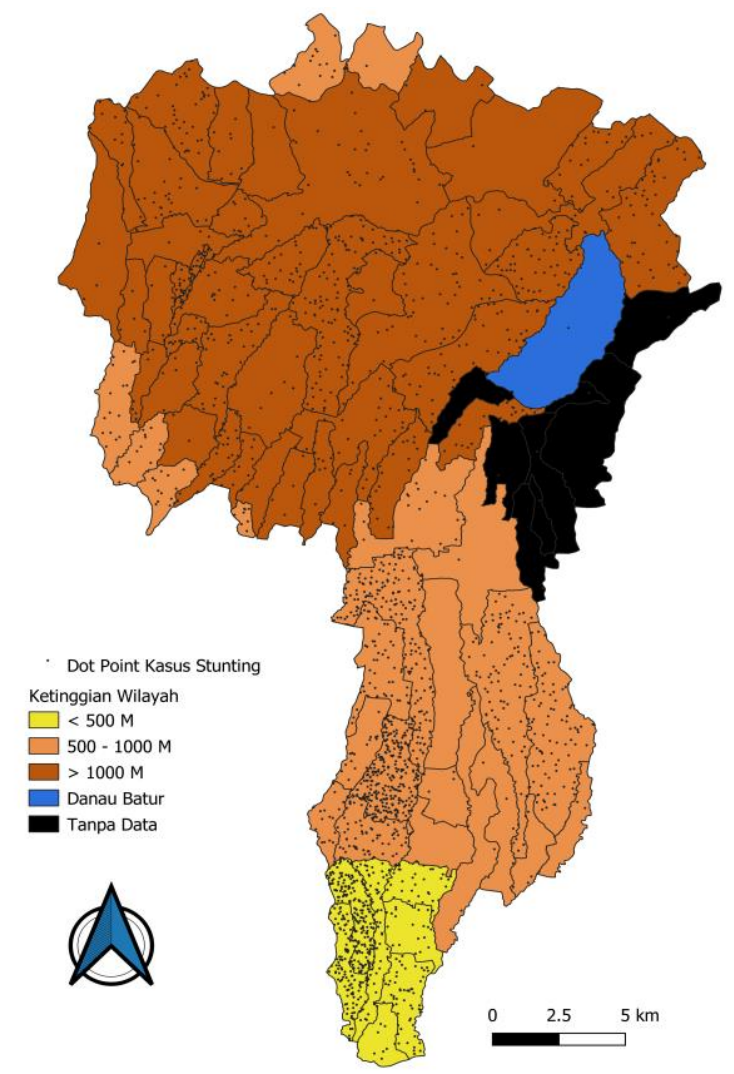

\section{Gambar 4. Distribusi Kasus Stunting Dengan Zona Ekosistem Daerah di Kabupaten Bangli Tahun 2019}

Di Kecamatan Bangli pada beberapa daerah seperti Bunutin, Bebalang, Kawan dan Taman Bali berada di ketinggian < $500 \mathrm{M}$, kasus stunting di daerah tersebut terlihat tersebar secara merata, walau Desa Bunutin memiliki kasus yang relatif kecil yakni 9 kasus. Sedangkan daerah lainnya di Kecamatan Bangli berada dalam ketinggian 500 - 1000 M, seperti Kayubihi, Cempaga dan Landih. Daerah Kayubihi dan Cempaga tercatat tidak memiliki kasus stunting pada tahun 2019 berada di dataran sedang. Kecamatan Susut juga sebagain daerahnya berada di bawah $500 \mathrm{M}$ seperti Demulih, Apuan dan Abuan. Untuk daerah Apuan dan Abuan memiliki kasus stunting yang sangat tinggi jika dibandingkan daerah lain. Sedangkan untuk daerah Susut lainnya berada di ketinggian 500 - $1000 \mathrm{M}$ dengan jumlah kasus stunting yang juga relatif tinggi. Di Kecamatan Tembuku keseluruhan wilayahnta berada pada ketinggian 500 1000 M. Kasus stunting di Kecamatan Tembuku cenderung bervariasi, di Desa Peninjoan dan Yangapi kasus stunting cukup tinggi, namun di desa lainnya kasus cukup rendah. Kecamatan Kintamani merupakan kecamatan yang rata - rata daerahnya berada di ketinggian $>1000$ M, dan kejadian stunting di Kecamatan Kintamani cenderung merata tedapat di seluruh desa - desa tersebut di Kecamatan Kintamani, walau ada beberapa wilayah yang jumlah kasusnya tidak diketahui. 
Pada gambar 4 terlihat bahwa kejadian stunting terjadi di seluruh wilayah dataran rendah, dataran sedang, dan dataran tinggi atau pegunungan di Kabupaten Bangli. Pada penelitian yang dilakukan oleh Haile dkk (2016) menunjkan hasil bahwa kejadian stunting lebih banyak ditemukan di wilayah bagian utara Ethiopia yang mana daerah tersebut memiliki karakteristik dataran sedang dan dataran tinggi. Hal tersebut juga sejalan dengan hasil yang ditemukan oleh Hagoset et al yang menemukan kasus stunting di Ethiopia lebih sering terjadi pada daerah dataran tinggi dan sedang dari pada dataran rendah. Penelitian lain yang dilakukan di Manggarai oleh Danila et al (2010) menemukan nilai Moran's stunting sebesar 0,45 dengan nilai $p$ 0,0001 pada variabel ketinggian wilayah dari permukaan laut. Hal tersebut menunjukan kasus stunting secara signifikan lebih tinggi di wilayah pegunungan di Kabupten Manggarai. Gambar 4 menunjukan kejadian stunting tertinggi ada di Desa Sulahan, Kecamatan Susut yang mana daerah tersebut berada di dataran sedang. Desa Yangapi dan Peninjoan, Tembuku juga memiliki kasus stunting yang cukup tinggi berada di dataran sedang. Kemudian kejadian stunting di Kecamatan Kintamani terjadi di seluruh desa - desa dengan jumlah yang bervariasi, yang mana Kecamatan Kintamani sebagian besar wilayahnya merupakan dataran pegunungan dan sisanya dataran sedang. Kecamatan Bangli merupakan kecamatan yang hampir setengah wilayahnya berada di dataran rendah, korelasi tersebut terlihat dengan
Kecamatan Bangli merupakan kecamatan dengan kasus stunting terendah.

Pada beberapa desa seperti Abuan dan Apuan meskipun terletak di dataran rendah namun memiliki kasus stunting yang cukup tinggi. Hal tersebut juga dijelaskan dalam penelitian Haile dkk (2016), dimana variasi kejadian stunting juga dipengaruhi oleh vaktor - vaktor lain. Vaktor - vaktor lain yang ditemukan dalam penelitian tersebut antara lain lingkungan dan geografi (cuaca, iklim, dan penyakit yang sering terjadi di lingkungan tersebut), kepadatan penduduk, faktor individu (usia, jenis kelamin, status imunisasi, riwayat anemia), dan faktor rumah tangga (tingkat pendidikan orang tua, jumlah anggota keluarga, jumlah anak). faktor - faktor tersebut bisa saja mempengaruhi tingginya kejadian stunting di Desa Abuan dan Apuan.

Sebuah penelitian yang dilakukan oleh oleh Cahyono (2016) menemukan ada perbedaan faktor - faktor risiko kejadian stunting di masing - masing zona wilayah. Berdasarkan analisis multivarian faktor penentu stunting pada zona ekosistem dataran rendah adalah asupan energy. Faktor penentu stunting di zona dataran sedang adalah praktik kasih sayang dan sanitasi lingkungan; dan di zona eksosistem pegunungan adalah sanitasi lingkungan. Terdapat perbedaan yang sangat bermakna $(p<0,05)$ pada variabel tingkat pendapatan, konsumsi energi, konsumsi protein, jenis makanan, praktik higiene kesehatan dan praktik kasih sayang terhadap kejadian stunting antar zona ekosistem di Kabupaten Kupang. (Firmanu Cahyono et al., 2016). Jika dilihat 
pada Kecamatan Bangli yang sebagian daerahnya adalah dataran rendah jumlah KEK pada ibu hamil pada tahun 2018 pada profil kesehatan Kabupaten Bangli menunjukan UPT Bangli dan UPT Bangli Utara secara berurutan adalah 24 dan 16 orang, dimana angka tersebut cukup tinggi jika dibandingkan KEK pada puskesmas lainnya di Kabupaten Bangli, kemungkinan hal tersebut dapat menjelaskan penemuan kasus yang cukup tinggi di beberapa wilayah Kecamatan Bangli.

\section{Distribusi Kasus Stunting Dengan} Cakupan JSP (Jamban Sehat Permanen) di Kabupaten Bangli

Kepemilikan jamban sehat sangat penting dalam penanganan kasus stunting. Jamban berfungsi sebagai tempat penampungan kotoran manusia agar tidak mencmari lingkungan. Pencemaran lingkungan akibat kotoran manusia sangat membahayakan, salah satunya dapat menimbulkan diare apabila terjadi pencemaran pada air baku. Diare merupakan salah satu faktor yang mempengaruhi kejadian stunting.

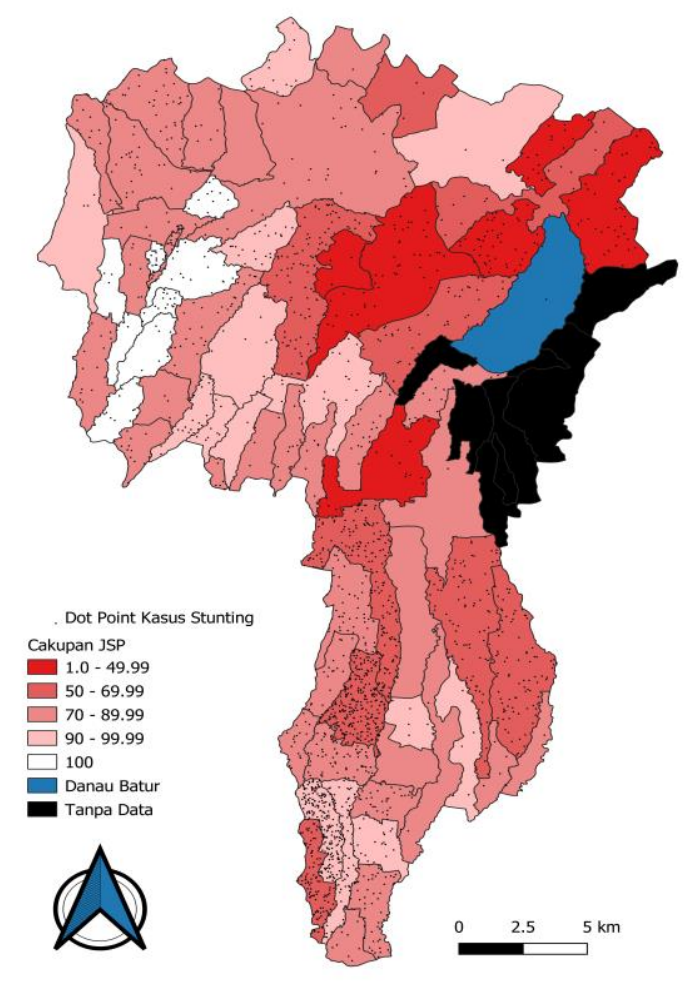

Gambar 5. Distribusi Kasus Stunting Dengan Cakupan JSP Per Desa Di Kabupaten Bangli Tahun 2019

Beberapa daerah di Kecamatan Susut yang memiliki kasus stunting tinggi seperti Sulahan, Tiga, dan Apuan juga memiliki cakupan JSP yang lebih rendah dibandingkan daerah sekitarnya. Bahkan Sulahan menjadi desa dengan kasus stunting tertinggi di Kabupaten Bangli
(259 kasus) dengan cakupan JSP yang rendah. Desa Peninjoan dan Yangapi di Kecamatan Tembuku juga memiliki kasus stunting yang cukup tinggi dan cakupan JSP dibawah 70\%. Beberapa daerah di sekitaran Danau Batur seperti Desa Abang Batu Dinding, Batur Utara, Batur Selatan, 
Soangan B, dan Belandingan bahkan memiliki cakupan JSP dibawah 50\%, dimana kasus stunting di daerah tersebut ada di semua desa dengan frekuensi yang bervariasi. Daerah di Kecamatan Kintamani lainnya yang memiliki cakupan JSP rendah adalah di daerah Desa Kintamani, dengan kasus stunting sebanyak 107 balita.

Desa / Kelurahan di Kecamatan Bangli sebagian besar telah memiliki cakupan JSP yang tinggi, kecuali di Desa Pengotan yang masih dibawah 50\% dengan kasus stunting sebanyak 19 kasus. Dua wilayah yang tanpa kasus stunting yakni Kayubihi dan Cempaga memiliki cakupan JSP yang cukup baik. Beberapa Desa di Kecamatan Kintamani seperti Batukaang, Binyan, Ulian, Daup, Bunutin, Awan, dan Gunung Bau telah memiliki cakupan JSP mencapai 100\%, kasus stunting di desa tersebut juga tergolong rendah yakni yang terendah 4 kasus di Batukaang dan yang terbanyak di Desa Awan dan Gunungbau sebanyak 16 kasus. Daerah - daerah yang memiliki cakupan JSP diatas $90 \%$ rata - rata memiliki kasus stunting yang rendah yakni dibawah 30 kasus.

Beberapa wilayah meskipun telah memiliki cakupan JSP yang baik namun tetap memiliki kasus stunting yang tinggi. Desa Abuan di Kecamatan Susut memiliki cakupan JSP diatas 90\% namun kasus stunting di daerah tersebut masih tinggi yakni 201 kasus. Wilayah Demulih, Susut juga memiliki cakupan JSP yang baik namun kasus stunting masih tinggi yakni 61 kasus. Desa Taman Bali, Bangli juga memiliki cakupan JSP yang tinggi namun dengan kasus stunting yang relatif tinggi
(55 kasus) jika dibandingkan daerah di sekitarnya.

Pencemaran lingkungan akibat kotoran manusia sangat membahayakan, salah satunya dapat menimbulkan diare apabila terjadi pada air baku. Diare merupakan salah satu faktor yang mempengaruhi kejadian stunting. Berdasarkan data WHO dan UNICEF (2013) kejadian open defecation (buang air besar sembarangan) yang tinggi pada 20 negara berhubungan langsung dengan tingginya angka prevalensi stunting di 17 negara dari 20 neragara tersebut yakni sebesar 35\% atau lebih (Chambers \& Medeazza, 2013).

Pada gambar 5 menggambarkan peta sebaran kasus stunting dengan cakupan JSP per desa. Beberapa daerah di Kecamatan Susut yang memiliki kasus stunting tinggi seperti Sulahan, Tiga, dan Apuan juga memiliki cakupan JSP yang lebih rendah dibandingkan daerah sekitarnya. Bahkan Sulahan menjadi desa dengan kasus stunting tertinggi di Kabupaten Bangli (259 kasus) dengan cakupan JSP 63,28\%. Hal tersebut sesuai dengan hasil penelitian yang dilakukan oleh Nadiyah dkk (2014) menemukan terdapat hubungan yang signifikan antara sanitasi kurang baik dengan stunting $(\mathrm{p}<0.005)$. Sanitasi lingkungan yang kurang baik menjadi faktor risiko stunting (OR=1.46; $\mathrm{p}<0.05)$. Kurangnya sistem pembuangan air limbah/kotoran yang cukup berhubungan dengan defisitnya tinggi badan anak $0.9 \mathrm{~cm}(95 \% \mathrm{CI}=0.2-1.7$ $\mathrm{cm})$ saat usia 24 bulan. Anak dengan kondisi air dan sanitasi kurang baik 54\% lebih sering mengalami diare daripada anak yang kondisi air dan sanitasinya 
paling baik (Nadiyah, Briawan, \& Martianto, 2014).

$$
\text { Pada peta } 5 \text { menunjukkan }
$$

Kecamatan Bangli sebagian besar telah memiliki cakupan JSP yang tinggi, kecuali di Desa Pengotan yang hanya 37,31\% dengan kasus stunting sebanyak 19 kasus. Dua wilayah yang tanpa kasus stunting yakni Kayubihi dan Cempaga memiliki cakupan JSP diatas 78\%. Beberapa Desa di Kecamatan Kintamani seperti Batukaang, Binyan, Ulian, Daup, Bunutin, Awan, dan Gunung Bau telah memiliki cakupan JSP mencapai $100 \%$, kasus stunting di desa tersebut juga tergolong rendah yakni yang terendah 4 kasus di Batukaang dan yang terbanyak di Desa Awan dan Gunungbau sebanyak 16 kasus. Daerah - daerah yang memiliki cakupan JSP diatas $90 \%$ rata rata memiliki kasus stunting yang rendah yakni dibawah 30 kasus. Selain penelitian yang dilakukan oleh Nadiyah dkk, beberapa penelitian lain juga menguatkan hubungan antaran kejadian stunting dengan akses jamban, sebuah penelitian di Sidoarjo menjelaskan bahwa ada hubungan antara penerapan jamban sehat dengan kejadian diare $(p=0,014)$ mengingat diare merupakan faktor risiko dan berkontribusi dalam kejadian stunting (Kh \& Muniroh, 2019).

Beberapa wilayah meskipun telah memiliki cakupan JSP yang baik namun tetap memiliki kasus stunting yang tinggi. Desa Abuan di Kecamatan Susut memiliki cakupan JSP mencapai 97,97\% namun kasus stunting di daerah tersebut masih tinggi yakni 201 kasus. Wilayah Demulih, Susut juga memiliki cakupan JSP 92.03\% namun kasus stunting masih tinggi yakni 61 kasus. Desa Taman Bali, Bangli juga memiliki cakupan JSP yang tinggi $(92.57 \%)$ namun dengan kasus stunting yang cukup tinggi (55 kasus) jika dibandingkan daerah lainnya. Hal tersebut mungkin saja terjadi akibat jenis kepemiliki jamban yang kurang layak seperti oleh masyarakatnya. Sebuah penelitian yang dilakukan oleh Zairiyanti \& Purnama (2019) menemukan balita yang tinggal di rumah dengan jenis jamban yang tidak memenuhi syarat mempunyai risiko untuk mengalami stunting 0,3 kali lebih besar dibandingkan balita yang tinggal dengan jenis jamban yang memenuhi syarat (Zairinayati \& Purnama, 2019). Kejadian stunting memang tidak selalu dipengaruhi hanya oleh akses jamban, pada penelitian yang dilakukan oleh Uwiringiyimana et al (2019) telah melakukan penelitian multi variabel namun tidak menemukan hubungan yang bermakana antara kejadian stunting dengan sanitasi lingkungan di daerah tersebut (Uwiringiyimana, Veldkamp, \& Amer, 2019).

\section{SIMPULAN}

Sebaran kasus stunting per desa dan kecamatan di Kabupaten Bangli dapat ditampilkan dalam gambar peta Distribusi Kasus Stunting Per Desa di Kabupaten Bangli Tahun 2019 dan Distribusi Kasus Stunting Per Kecamatan di Kabupaten Bangli Tahun 2019 dimana kejadian stunting banyak terjadi di Kecamatan Susut dan yang terendah di Kecamatan Bangli. Gambaran pola kejadian stunting dengan faktor risiko jarak jangkauan pusat pelayanan kesehatan dapat ditampilkan dalam gambar peta Distribusi Kasus Stunting Dengan Jangkauan Wilayah 
Puskesmas di Kabupaten Bangli Tahun 2019 dimana beberapa daerah yang jauh dari layanan puskesmas memiliki kasus stunting yang tinggi. Gambaran pola kejadian stunting dengan faktor risiko daerah rural dan urban dapat ditampilkan dalam gambar peta Distribusi Kasus Stunting Dengan Status Rural Urban Desa di Kabupaten Bangli Tahun 2019 dimana kasus stunting di wilayah urban cenderung lebih rendah. Gambaran pola kejadian stunting dengan faktor risiko zona ekosistem dataran dapat ditampilkan dalam gambar peta Distribusi Kasus Stunting Dengan Zona Ekosistem Daerah di Kabupaten Bangli Tahun 2019 dengan kasus stunting paling banyak terjadi di dataran tinggi dan sedang. Pola kejadian stunting dengan faktor risiko cakupan jambar sehat dapat ditampilkan dalam gambar peta Distribusi Kasus Stunting Dengan Cakupan JSP Per Desa di Kabupaten Bangli Tahun 2019 dan peta Distribusi Kasus Stunting Dengan Cakupan JSP Per Kecamatan di Kabupaten Bangli Tahun 2019 dimana cakupan JSP di Kecamatan Bangli yang paling baik dengan kasus stunting juga yang terendah.

\section{SARAN}

Dinas Kesehatan Kabupaten Bangli dapat memanfaatkan peta sebaran kasus stunting beserta faktor risikonya untuk memprioritaskan intervensi penanganan pada daerah - daerah dengan faktor risiko jauh dari pusat layanan puskesmas, berstatus wilayah rural, berada pada dataran sedang hingga tinggi, dan memiliki cakuan jamban yang kurang. Diharapkan selanjutnya dapat dilakukan penelitian lebih lanjut dengan menggunakan analisis spasial mengenai kejadian stunting di Kabupaten Bangli menggunakan metode Sistem Informasi Geografis (GIS).

\section{DAFTAR PUSTAKA}

Adimas Ketut Nalendra, Mochamad Bilal, I. Y. S. (2019). ISSN : 2338-4697 eISSN : 2579-3322. Jurnal Ekonomi Dan Teknik Informatika, 7(1), 45-50.

Almasi, A., Zangeneh, A., Saeidi, S., Rahimi Naderi, S., Choobtashani, M., Saeidi, F., () Ziapour, A. (2019). Study of the Spatial Pattern of Malnutrition (Stunting, Wasting and Overweight) in Countries in the World Using Geographic Information System. International Journal of Pediatrics, 7(10), 10269-10281. https://doi.org/10.22038/ijp.2019.4020 4.3410

Aprilliyani Pepi Lusita, Suyatno, \& Rahfiludin, M. Z. (2017). Perbedaan Karakteristik Balita Stunting Di Pedesaan Dan Perkotaan Tahun 2017 (Studi Pada Anak Usia 24-59 Bulan di Wilayah Kerja Puskesmas Gabus II dan Wilayah Kerja Puskesmas Pati II Kabupaten Pati). Jurnal Kesehatan Masyarakat (e-Journal), 5(4), 600-612.

Budiastutik, I., \& Rahfiludin, M. Z. (2019). Faktor Risiko Stunting pada anak di Negara Berkembang, 122-126. https://doi.org/10.2473/amnt.v3i3.201 9.122-129

Chambers, R., \& Medeazza, G. Von. (2013). Sanitation And Stunting In India Undernutrition's Blind Spot. Economic and Political Weekly, 48(25), 15-18.

Danila, Pawa, I. D., Choiruni, A., \& 
Wijayanti, A. (2019). Geospatial Analysis pada Prevalensi Stunting di Kabupaten Manggarai. UGM Public Health Symposium. https://doi.org/10.1371/journal.pone. 0154756

Departemen Kesehatan Republik Indonesia. (1991) Pedoman Kerja Puskesmas. Jakarta : Departemen Kesehatan

Dinkes Bali. (2018). Profil Kesehatan Provinsi Bali 2017. Dinas Kesehatan Provinsi Bali.

Dinkes Bangli. (2019). Profil Kesehatan Kabupate Bangli 2018. Dinas Kesehatan Kabupaten Bangli, 4(1), 7584. https://doi.org/.1037//00332909.I26.1.78

Firmanu Cahyono, Manongga, S. P., \& Intje Picauly. (2016). Faktor Penentu Stunting Anak Balita Pada Berbagai Zona Ekosistem Di Kabupaten Kupang, 11(1), 9-18.

Francisco, J., Ferrer, L., \& Serra-majem, L. (2017). Factors Associated with Stunting among Children Aged 0 to 59 Months from the Central Region of Mozambique. MDPI Nutrient, 9, 116. https://doi.org/10.3390/nu9050491 Haile, D., Azage, M., Mola, T., \& Rainey, R. (2016). Exploring spatial variations and factors associated with childhood stunting in Ethiopia: Spatial and multilevel analysis. BMC Pediatrics, 16(1), 1-14. https://doi.org/10.1186/s12887-0160587-9

Kazwaini, M., \& Nugraheni, W. (2014). Evaluasi Sistem Surveilans Ibu Hamil, Bayi dan Balita di Puskesmas Unit I, Puskesmas Moyo Hulu dan
Dinas Kesehatan Kabupaten Sumbawa. Buletin Penelitian Sistem Kesehatan, $\quad 17(1 \quad$ Jan), 1-7. https://doi.org/10.22435/bpsk.v17i1

Kemenkes RI. (2018). Buletin Stunting. Kementerian Kesehatan Republik Indonesia, 301(5), 1163-1178.

Kh, A. airil S., \& Muniroh, L. (2019). Hubungan Faktor Water, Sanitation , and Hygiene ( WASH ) dengan Stunting di Wilayah Kerja Puskesmas Kotakulon, Kabupaten Bondowoso. Amerta Nutrition, 164-170. https://doi.org/10.2473/amnt.v3i3.201 9.164-170

Laksono, A. D., \& Kusrini, I. (2019). Gambaran Prevalensi Balita Stunting dan Faktor yang Berkaitan di Indonesia: Analisis Lanjut Profil Kesehatan Indonesia Tahun 2017 https://doi.org/10.13140/RG.2.2.35448 .70401

Ma'Rifat. (2010). Analisis Hubungan Pemanfaatan Pelayanan Kesehatan Dengan Status Gizi Anak Batita. Institut Pertanian Bogor.

Madan, J. (2014). Exploring Relationships Between Stunting And Distance To Health Centers And Commune Capitals In Mali. Tufts University, 87(December), 2014. Retrieved from Tufts university

Megawaty, D. A., \& Simanjuntak, R. Y. (2017). Pemetaan Penyebaran Penyakit Demam Berdarah Dengue Menggunakan Sistem Informasi Geografis pada Dinas Kesehatan Kota Metro. Explore: Jurnal Sistem Informasi Dan Telematika, 8(2). https://doi.org/10.36448/jsit.v8i2.954

Nadiyah, Briawan, D., \& Martianto, dan 
D. (2014). Faktor Risiko Stunting Pada Anak Usia 0 - 23 Bulan Di Provinsi Bali , Jawa Barat, Dan Nusa Tenggara Timur. Jurnal Gizi Dan Pangan, 9(2), 125-132.

Riskesdas, K. (2018). Hasil Utama Riset Kesehata Dasar (RISKESDAS). Journal of Physics A: Mathematical and Theoretical, 44(8), 1-200. https://doi.org/10.1088/17518113/44/8/085201

Sartika, R. A. D. (2010). Analisis Pemanfaatan Program Pelayanan Kesehatan Status Gizi Balita. Jurnal Kesehatan Masyarakat Nasional, 5(2), 76-83.

Tim Nasional Percepatan Penanggulangan Kemiskinan (TNP2K). (2017). 100

Kabupaten/Kota Prioritas Untuk Intervensi Anak Kerdil (STUNTING). Sekretariat Wakil Presiden RI, 1.

Uwiringiyimana, V., Veldkamp, A., \& Amer, S. (2019). Stunting Spatial Pattern In Rwanda: An Examination Of The Demographic, SocioEconomic And Environmental Determinants. Geospatial Health, (November).

https://doi.org/10.4081/gh.2019.820

Zairinayati, \& Purnama, R. (2019). Hubungan Hygiene Dan Sanitasi Lingkungan Dengan Kejadian Stunting Pada Balita. Jurnal Ilmiah Multi Science Kesehatan, 10. 